\title{
Mechanical Characteristics of Superaustenitic Stainless Steel Type 30Cr25Ni32Mo3 at Elevated Temperatures
}

\author{
Gholam Reza Ebrahimi $^{1}$, Hamid Keshmiri ${ }^{2}$, Hadi Arabshahi ${ }^{3}$ \\ ${ }^{1}$ Metallurgy and Materials Engineering Department, Sabzavar Tarbiat Moallem University, Sabzevar, Iran; ${ }^{2}$ Esfarayen Industrial \\ Complex, Esfarayen, Iran; ${ }^{3}$ Physics Department, Ferdowsi University of Mashahd, Mashahd, Iran. \\ E-mail: g.rebrahimi@yahoo.com
}

Received October $26^{\text {th }}, 2010$; revised November $17^{\text {th }}, 2010$; accepted December $3^{\text {rd }}, 2010$.

\begin{abstract}
In making tubes of corrosion resistant and hardly deformed steels and alloys, the pilger rolling method is used for hot rolling of final thick-walled tubes or mother tubes of large diameters (above $300 \mathrm{~mm}$ ) and small quantities of other size tubes when no other, more efficient tube rolling or extrusion equipment is available. To clarify individual parameters of the production process and make choice of the deformation-and-temperature parameters, mechanical properties of the alloy type 30Cr25Ni32Mo3 Superaustenitic Stainless Steel at various temperatures were studied. The tests have been performed using samples taken from the forged $400 \mathrm{~mm}$ diameter billet to determine strength and plastic properties of the billet metal at various temperatures and its macro- and microstructure. The test results will be used in the choice of optimum conditions of preheating of the billets and hot rolling of tubes. On the whole, it should be stated that as-forged alloy 30Cr25Ni32Mo3 features a favorable combination of strength and plastic properties in the hot-working temperature range of $1075-1200^{\circ} \mathrm{C}$.
\end{abstract}

Keywords: Superaustenitic Stainless Steel, Hot Deformation, Mechanical Properties, Microstructure Evaluation

\section{Introduction}

The superaustenitic grades of stainless steels provide excellent corrosion resistance as well as high strength levels [1]. As the austenitic steels are characterized by their low Stacking Fault Energy (SFE) [2], the dominant restoration processes during and after hot Deformation are therefore dynamic and Metadynamic Recrystallizations (DRX and MDRX), respectively [3-7]. For the last two decades intensive studies have been down on the changes of austenitic microstructure and mechanical properties in steels with hot working conditions. Several thermomechanical processing technologies such as controlled rolling controlled cooling and direct quenching were developed through these studies. Some research have been done to determine the best plasticity temperature range using the thermomechanical processing such as hot compression and hot torsion tests in steels[8-12]. However, metallurgical studies are scarcely performed to characterize hot working behavior of superaustenitic stainless steels. In this research, mechanical properties accompanying with microstructural evaluation of the alloy type 30Cr25Ni32Mo3 Superaustenitic Stainless Steel at various temperatures were studied. For this purpose tensile and torsion tests at various temperatures from $800^{\circ} \mathrm{C}$ up to $1180^{\circ} \mathrm{C}$ and $1000^{\circ} \mathrm{C}$ up to $1200^{\circ} \mathrm{C}$ have been done respectively.

\section{Experimental Procedures}

The material used for virtually all the experiments in this work was a $30 \mathrm{Cr} 25 \mathrm{Ni} 32 \mathrm{Mo} 3$ super austenitic stainless steel obtained from a cross-section of the forged $400 \mathrm{~mm}$ diameter billet produced by EICO, IRAN. The chemical composition and as received microstructure of this steel are given in Table 1 and Figure 1 respectively. Mechanical properties at room temperature in as-received condition are given in Table 2. In tensile tests at room temperature, two types of specimens were used: conventional cylindrical specimens (type 3) and special fillet-neck specimens (type 4) designed for testing hardly deformed materials. A minor scatter of property readings was observed: the fillet-neck specimens had strength $\left(R_{m}\right.$; $\mathrm{Rp}_{0.2}$ ) levels somewhat lower and plastic property $(\mathrm{A} ; \mathrm{B})$ 
Table1. Chemical composition of the material used. (Wt \%)

\begin{tabular}{ccccccc}
\hline $\mathrm{C}$ & $\mathrm{Cr}$ & $\mathrm{Ni}$ & $\mathrm{Mo}$ & $\mathrm{Mn}$ & $\mathrm{P}$ & $\mathrm{S}$ \\
\hline 0.025 & 28.00 & 33.00 & 3.50 & 0.60 & 0.028 & 0.0015 \\
\hline
\end{tabular}

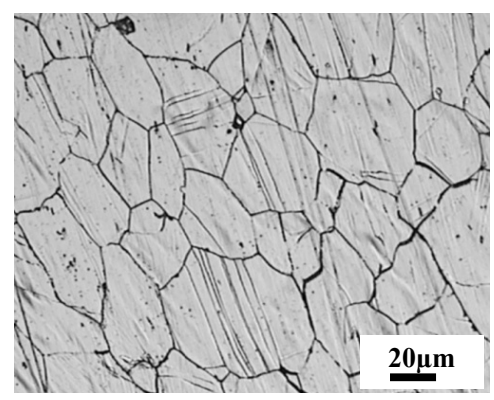

Figure 1. Microstructure of $30 \mathrm{Cr} 25 \mathrm{Ni32Mo3}$ in the as-received condition.

Table 2. Mechanical properties of the forged metal.

\begin{tabular}{ccccc}
\hline $\begin{array}{c}\text { Specimen } \\
\text { type }\end{array}$ & $\begin{array}{c}\mathrm{R}_{\mathrm{m}} \\
(\mathrm{MPa})\end{array}$ & $\begin{array}{c}\mathrm{R}_{\mathrm{p} 0.2} \\
(\mathrm{MPa})\end{array}$ & $\begin{array}{c}\text { Elongation, } \\
\mathrm{A} \%\end{array}$ & $\begin{array}{c}\text { Reduction of } \\
\text { area, B\% }\end{array}$ \\
\hline type 3 & 583 & 292 & 45,5 & 63 \\
type 4 & 579 & 289 & 46 & 64 \\
\hline
\end{tabular}

levels higher than conventional specimens but this difference was inessential.

The standard tensile test specimens according to ASTM A370 and special torsion samples (D = $8 \mathrm{~mm}$ ) were prepared in longitudinal direction of forged billets. Before testing, all the specimens subjected to solid solution heat treatment at $1250^{\circ} \mathrm{C}$ soaked for 15 minutes followed by cooling to the hot deformation temperature at a rate of $10^{\circ} \mathrm{Cs}^{-1}$. Before deformation, the specimens were held for $3 \mathrm{~min}$ at the deformation temperature to eliminate the thermal gradients as well as to ensure the uniform temperature of specimens. The tensile tests were then carried out at the temperatures between $800^{\circ} \mathrm{C}$ and $1180^{\circ} \mathrm{C}$ and between $1000^{\circ} \mathrm{C}$ and $1250^{\circ} \mathrm{C}$ at constant strain rate of $1 \mathrm{~s}^{-1}$ for torsion test. To preserve the microstructure, the samples were immediately quenched after hot deformation. The process of hot deformation test is shown schematically in Figure 2.

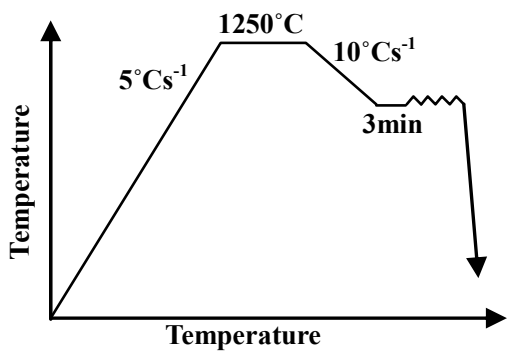

Figure 2. Thermal and thermomechanical cycles imposed on samples in this research.
After hot deformation testing, the torsion specimens were cut along the longitudinal axis for electrochemical polishing. Following this, the specimens were electrolitically etched in oxalic acid to reveal the microstructures. In order to follow the microstructural changes through hot deformation, the structure of samples were studied using both optical and scanning electron microscopy.

\section{Results and Discussion}

\subsection{Hot Tensile Tests}

Tensile test results for alloy $30 \mathrm{Cr} 25 \mathrm{Ni} 32 \mathrm{Mo} 3$ in the range of at 20 to $1180^{\circ} \mathrm{C}$ are shown graphically in Figure 3 .

Analysis of Figure 3(a) shows that as the test temperature increases, tensile strength and yield strength of alloy $30 \mathrm{Cr} 25 \mathrm{Ni} 32 \mathrm{Mo} 3$ decrease gradually and plastic properties (percent elongation and reduction of area) increase as well.

\subsection{Hot Torsion Tests}

Because of a lower plasticity of corrosion-resistant austenitic steels and alloys, it is of high importance to know the temperature range of plasticity of the studied material during its hot working. In order to determine the temperature range of an optimum plasticity of alloy $30 \mathrm{Cr} 25 \mathrm{Ni}$ $32 \mathrm{Mo} 3$, the method of hot torsion of special specimens was used to determine the material plasticity at the hot working temperatures. The number of torsions (n) and the torsion moment $\left(\mathrm{M}_{\mathrm{tor}}\right)$ at which the specimen fracture occurs are important indices of the material plasticity. Such indices are usually determined for various metal preheat temperatures.

This test method has been developed at State Enterprise "Ya. Ye. Osada Scientific Reseasrch Tube Institute" (SE "NITI"), Dnipropetrovsk, Ukraine, for mastering the technology of manufacture of tubes of hardly deformed steels and alloys and has been widely adopted in Ukrainian pipe and tube industry.

The tests were carried out with the use of special $8 \mathrm{~mm}$ diameter cylindrical specimens. The hot torsion test results are shown in Figure 4.

Alloy $30 \mathrm{Cr} 25 \mathrm{Ni} 32 \mathrm{Mo} 3$ reaches its maximum plasticity at test temperature of $1200^{\circ} \mathrm{C}$ and retains it up to $1250^{\circ} \mathrm{C}$. But it should be pointed out that minimal values of torque (MSKR) characterizing deformation resistance of alloy $30 \mathrm{Cr} 25 \mathrm{Ni} 32 \mathrm{Mo} 3$ are observed within the temperature range of $1100-1175^{\circ} \mathrm{C}$.

\subsection{Microstructural Observations}

The results of metallographic analysis of hot-torsion test specimens have shown that structure inhomogeneity remained in various specimens at $1050^{\circ} \mathrm{C}$. In a specimen fractured after 8.5 turns, grain variation was observed 


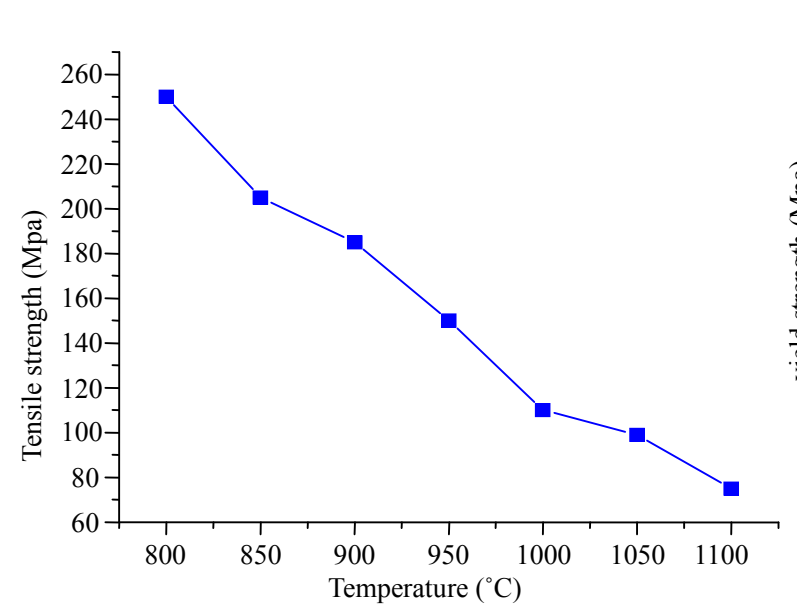

(a)

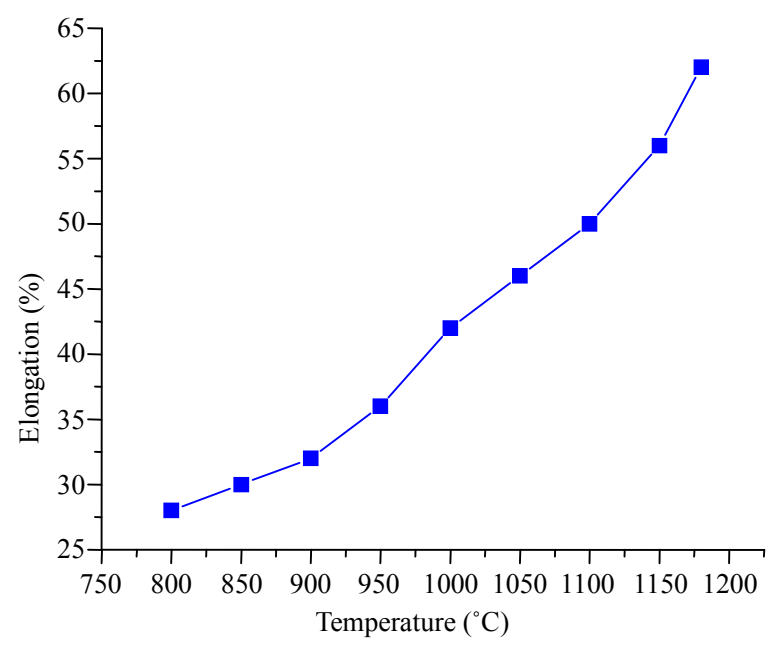

(c)

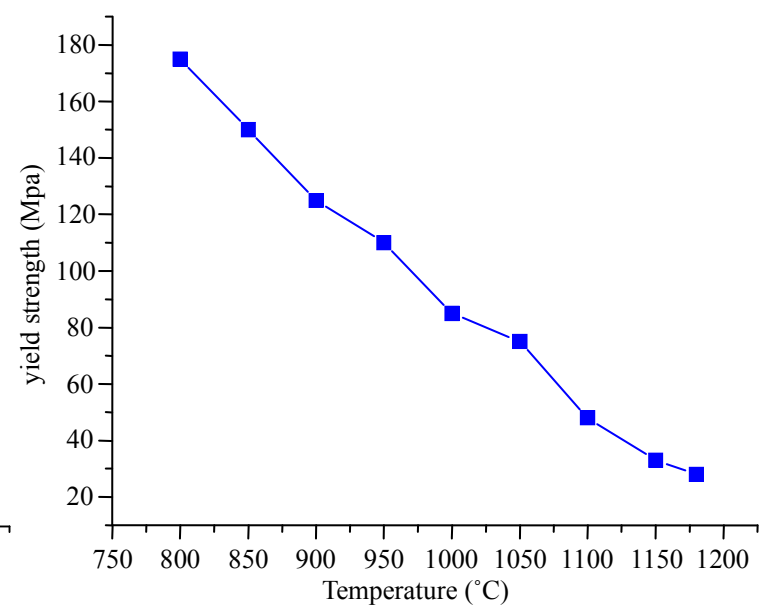

(b)

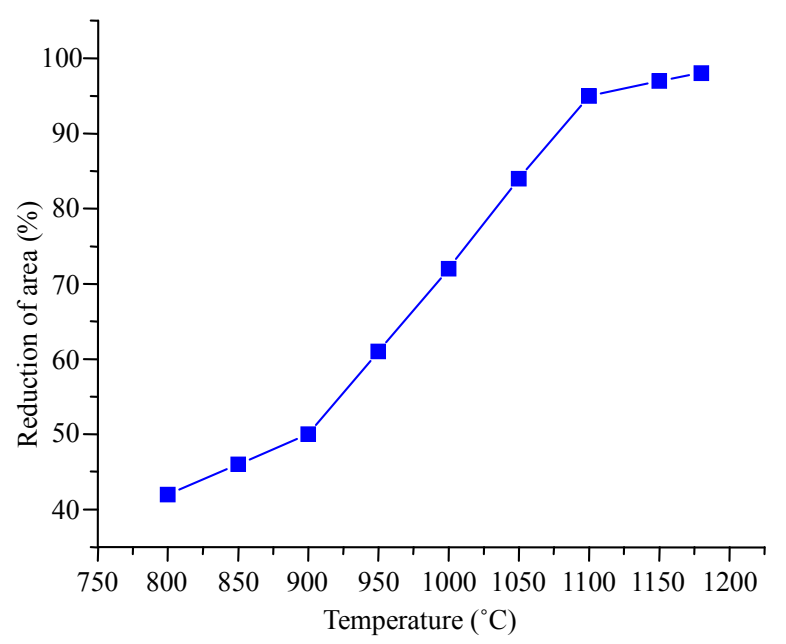

(d)

Figure 3. Tensile properties of alloy $30 \mathrm{Cr} 25 \mathrm{Ni32Mo3}$ at elevated temperatures. (a) Tensile strength, (b) Yield strength, (c) Percentage elongation, (d) Reduction of area.

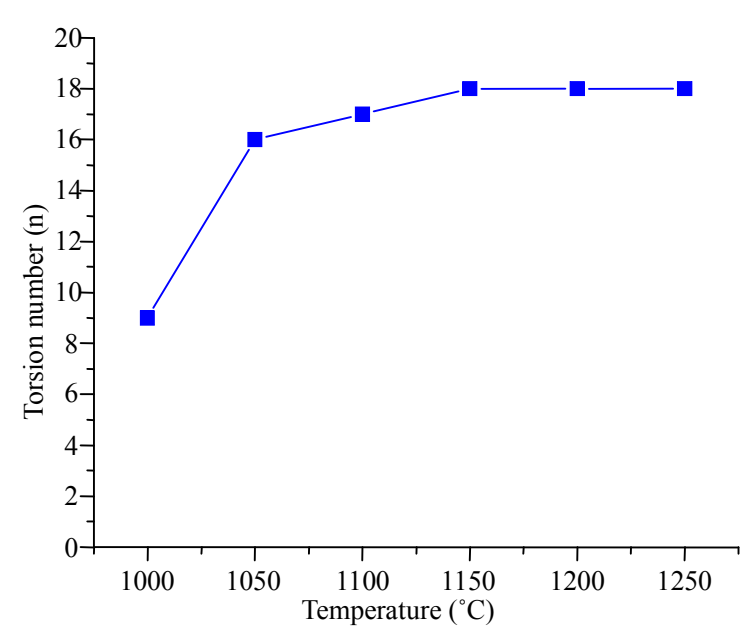

(a)

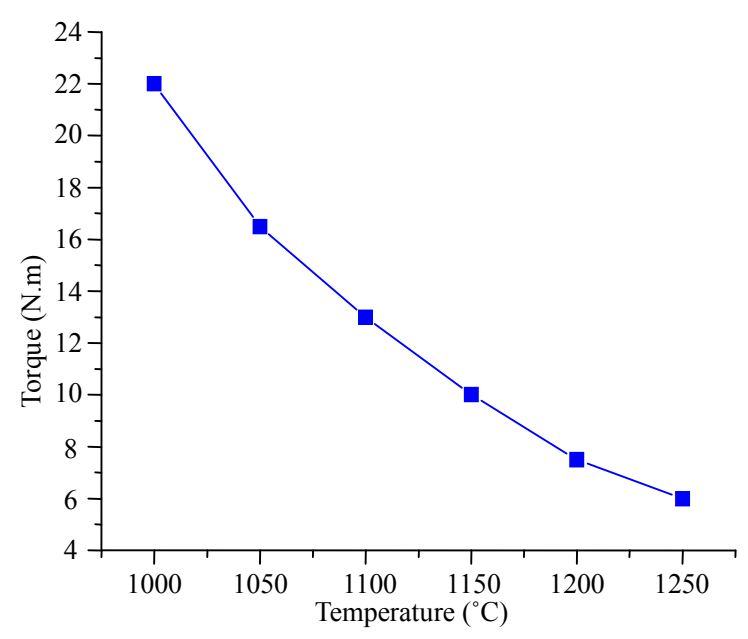

(b)

Figure 4. The test results of hot torsion of specimens made of alloys 30Cr25Ni32Mo3. (a) Torsion number, (b) Torque. 
(Figure 5(a)). In a specimen fractured after 34 turns, fine-grained and homogeneous structure with twin boundaries (Figure 5(b)) was present. Such condition of the alloy structure has influenced the test results.

As the test temperature grows, a significant coarsening of austenite grains (Figures 7(a-c)) and redistribution of alloying elements between the phases and the solid solution occur which explains the higher number of torsion turns.

To reveal probable fusion of the grain boundaries in the structure of metal of the investigated of alloy $30 \mathrm{Cr}$ $25 \mathrm{Ni} 32 \mathrm{Mo} 3$, quenching of the specimens heated to $1200^{\circ} \mathrm{C}$ was done first (Figure 8). Next, structure of the specimens torsion-tested at $1230^{\circ} \mathrm{C}$ (Figure 7(b)) and $1250^{\circ} \mathrm{C}$ (Figure 7(c)) was examined.

Structure examination of the specimens heated to 1200 $-1250^{\circ} \mathrm{C}$ has shown coarsening of austenite grains and presence of twin low-energy boundaries and phases in the structure.

No grain boundary fusion in metal of alloy $30 \mathrm{Cr} 25-$ Ni32Mo3 was revealed.

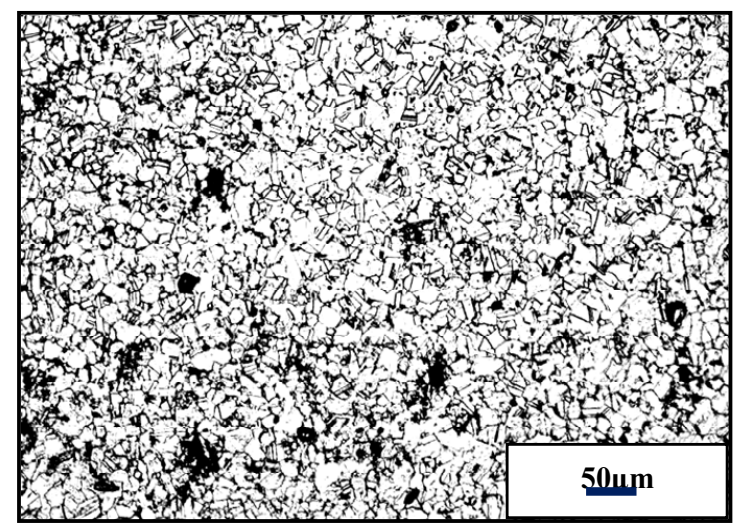

(a)

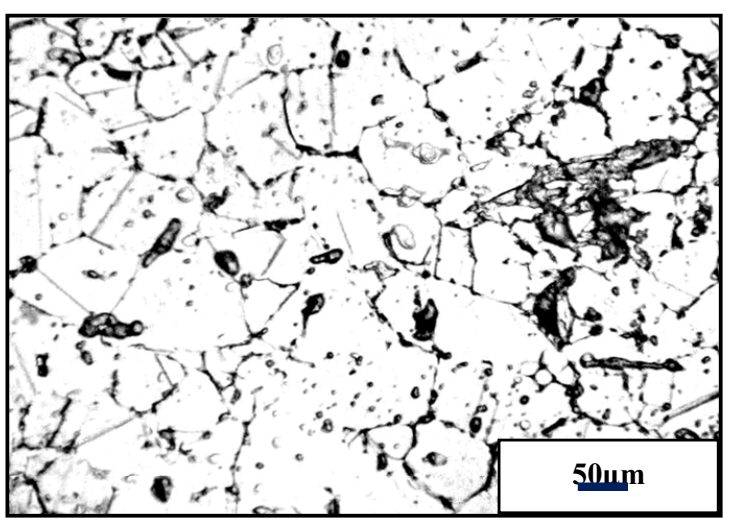

(b)

Figure 5. Microstructure of the specimens made of alloy $30 \mathrm{Cr} 25 \mathrm{Ni32Mo3}$ after hot torsion tests at $1050^{\circ} \mathrm{C}$. (a) Number of torsions 8.5, (b) Number of torsions 34 .

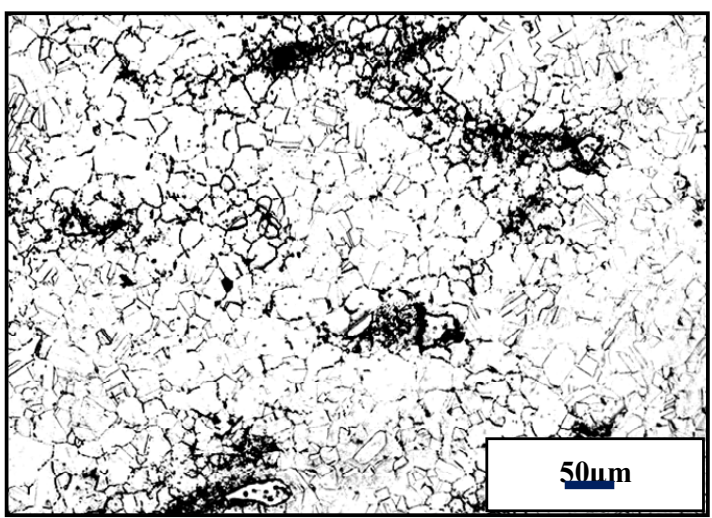

(a)

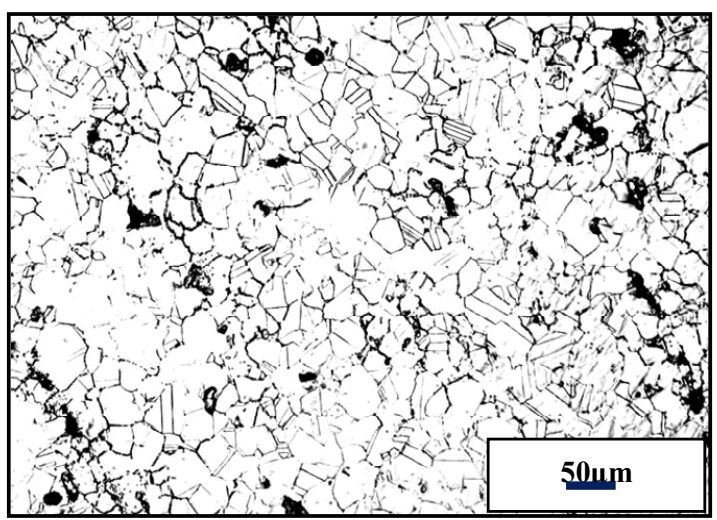

(b)

Figure 6. Microstructure of the specimens made of alloy $30 \mathrm{Cr} 25 \mathrm{Ni32Mo3}$ after hot torsion tests at (a) $1100^{\circ} \mathrm{C}$, (b) $1150^{\circ} \mathrm{C}$.

\section{Conclusions}

1) As the test temperature increases, tensile strength and yield strength of alloy $30 \mathrm{Cr} 25 \mathrm{Ni} 32 \mathrm{Mo} 3 \mathrm{de}-$ crease gradually and plastic properties (percent elongation and reduction of area) increase as well.

2) Alloy $30 \mathrm{Cr} 25 \mathrm{Ni} 32 \mathrm{Mo} 3$ reaches its maximum plasticity at test temperature of $1200^{\circ} \mathrm{C}$ and retains it up to $1250^{\circ} \mathrm{C}$. But it should be pointed out that minimal values of torque (MSKR) characterizing deformation resistance of alloy $30 \mathrm{Cr} 25 \mathrm{Ni} 32 \mathrm{Mo} 3$ are observed within the temperature range of $1100-1175^{\circ} \mathrm{C}$.

3) The results of metallographic analysis of hot-torsion test specimens have shown that structure inhomogeneity remained in various specimens at $1050^{\circ} \mathrm{C}$. In a specimen fractured after 8.5 turns, grain variation was observed. In a specimen fractured after 34 turns, fine-grained and homogeneous structure with twin boundaries was present.

4) As the test temperature grows, a significant coarsening of austenite grains and redistribution of alloy- 
ing elements between the phases and the solid solution occur which explains the higher number of torsion turns.

5) Structure examination of the specimens heated to $1200-1250^{\circ} \mathrm{C}$ has shown coarsening of austenite grains and presence of twin low-energy boundaries and phases in the structure.

6) No grain boundary fusion in metal of alloy $30 \mathrm{Cr} 25$ Ni32Mo3 was revealed.

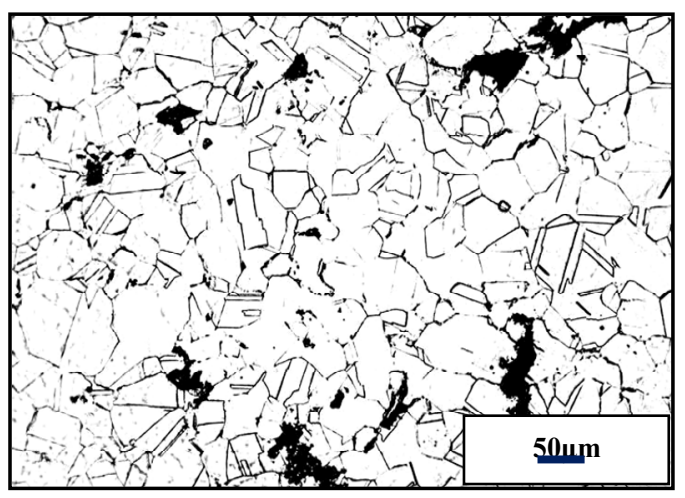

(a)

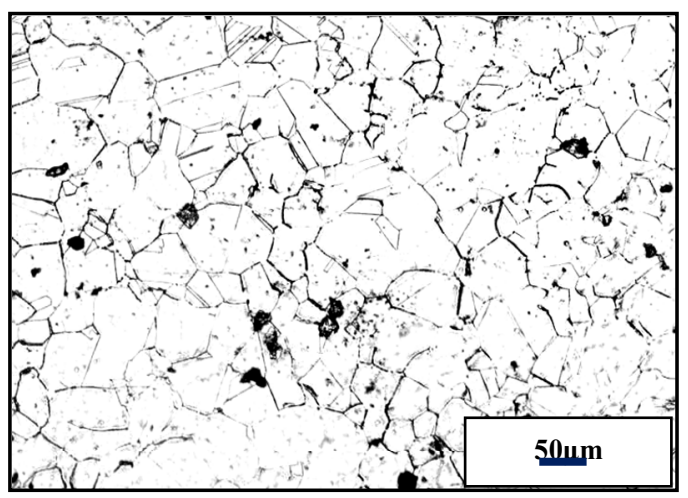

(b)

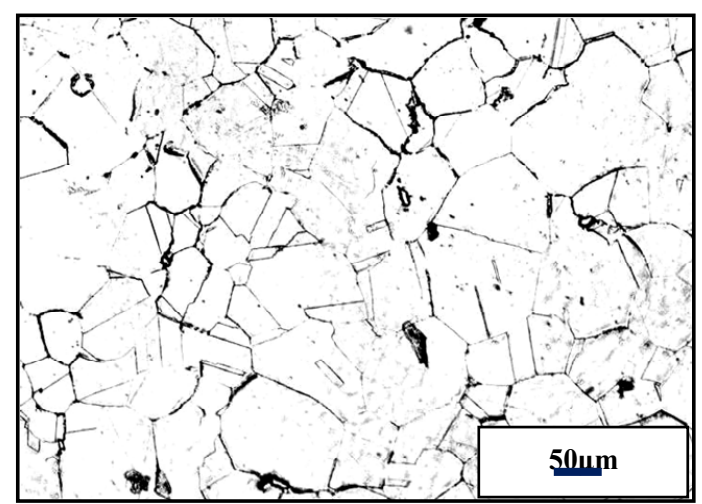

(c)

Figure 7. Microstructure of the specimens made of alloy $30 \mathrm{Cr} 25 \mathrm{Ni32Mo3}$ after hot torsion tests at (a) $1200^{\circ} \mathrm{C}$, (b) $1230^{\circ} \mathrm{C}$, (c) $1250^{\circ} \mathrm{C}$.

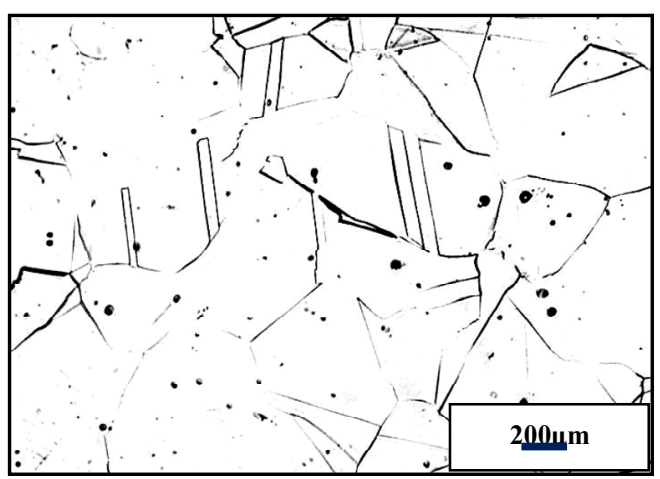

(a)

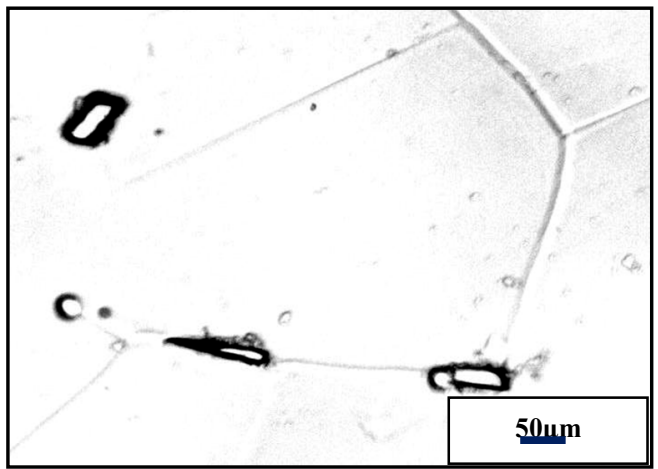

(b)

Figure 8. Microstructure of the specimens made of alloy $30 \mathrm{Cr} 25 \mathrm{Ni} 32 \mathrm{Mo3}$ after quenching at $1200^{\circ} \mathrm{C}$ from a separate heating: (a) General view, (b) Phase precipitates.

\section{REFERENCES}

[1] A. Momeni, K. Dehghani, H. Keshmiri and G. R. Ebrahimi, "Hot Deformation Behavior and Microstructural Evolution of a Superaustenitic Stainless Steel," Journal of Materials Science and Engineering A, Vol. 527, No. 6, 2010, pp. 1605-1611.

[2] F. J. Humphreys and M. Hatherly, "Recrystallization and Related Annealing Phenomena," 1st Edition, Pergamon Press, London, 1995.

[3] A. Belyakov, H. Miura and T. Sakai, "Dynamic Recrystallization in Ultra-Fine Grained 304 Stainless Steel," Scripta Materialia, Vol. 43, No. 1, 2000, pp. 21-26.

[4] S. I. Kim and Y. C. Yoo, "Dynamic Recrystallization Behavior of AISI 304 Stainless Steel," Materials Science and Engineering A, Vol. 311, No. 1-2, 2001, pp. 108-113.

[5] M. C. Mataya, E. R. Nilsson, E. L. Brown and G. Krauss, "Hot Working and Recrystallization of As-Cast 316 L," Metallurgical and Materials Transactions A, Vol. 34, No. 8, 2003, pp. 1683-1703.

[6] S. H. Cho and Y. C. Yoo, "Metadynamic Recrystallization of Austenitic Stainless Steelmater," Journal of Materials Science, Vol. 36, No. 17, 2001, pp. 4279-4284.

[7] A. Najafizadeh, J. J. Jonas, G. R. Stewart and E. I. Poliak, 
"The Strain Dependence of Post-Dynamic Recrystallization in 304H Stainless Steel," Metallurgical and Materials Transactions A, Vol. 37, No. 6, 2006, pp. 1899-1906.

[8] E. Bernstock-Kopaczyńska, I. Bed Narczyk, M. Jabłońska, G. Niewielski and D. Kuc, "The Influence of ThermoMechanical Treatment on the Structure and Plasticity of FeAl Intermetallic Phase-Base Alloy," Archives of Civil and Mechanical Engineering, Vol. 8, No. 3, 2008, pp. 15-22.

[9] J. M. Rodriguez-Ibabe, I. Gutiérrez, B. López and A. Iza-Mendia, "Relationship between Microstructure and Texture Development during the Early Stages of Annealing in Warm Rolled Low Carbon Steels," Materials Science Forum, Vol. 500-501 (Microalloying for New Steel
Processes and Applications), 2005, pp. 795-802.

[10] G. Niewielski, K. Radwanski and D. Kuc, "The Influence of Hot-Working Processing on Plasticity and Structure of Duplex Steel," Material Science \& Engineering, Vol 28, No. 6, 2007, pp. 325-332.

[11] H. Yada, C. M. Li and H. Yamagata, "Dynamic $\gamma \rightarrow \alpha$ Transformation during Hot Deformation in Iron-Nickel-Carbon Alloys," ISIJ International, Vol. 40, No. 2, 2000, pp. 200-206.

[12] A. Schmitz, J. Neutjens, J. C. Herman, and V. Leroy, "New Thermomechanical Hot Rolling Schedule for the Processing of High Strength Fine Grained Multiphase Steels," ISS Technical Paper, A. Schmitz, 1998, pp. 1-14. 